\title{
Retórica y educación: una propuesta interpretativa para la Retórica de Aristóteles
}

\author{
Octavio García-Aguilar \\ Estudiante de posgrado en la Coordenação de Aperfeiçoamento \\ de Pessoal de Nível Superior, Universidade Federal do Ceará, Fortaleza, Brasil \\ garciaoctavio14@gmail.com
}

Recibido: 15 de marzo del 2019

Corregido: 02 de mayo del 2019

Aceptado: 03 de setiembre del 2019

\begin{abstract}
Resumen
Durante los siglos cuarto y quinto antes de Cristo, en la ciudad-estado de Atenas se desarrolló un vivo debate alrededor de la pregunta ¿cómo educar? Los mecanismos heredados de la educación, la poesía homérica y la sabiduría gnómica comenzaron a ser reemplazados por teorías sistemáticas de la educación. Sin embargo, uno de sus más grandes teóricos, Aristóteles, legó una teoría incompleta debido a la desaparición de los libros de la Política que contenían el desarrollo de su teoría. Este ensayo plantea que se puede reconstruir parte de esta teoría interpretando la Retórica desde la pregunta por la educación. Para ello se expone como hipótesis que la Retórica contiene esbozos de una teoría de la educación, y se desarrollan tres argumentos principales: 1) la Retórica contiene una teoría de la educación, pues el joven, según los caracteres analizados por Aristóteles, no es una entidad política, por lo cual la Retórica además de política tiene un alcance educativo; 2) el discurso epidíctico teorizado en la Retórica tiene un carácter educativo, pues su finalidad consiste en transformar el comportamiento de los jóvenes conforme a los cánones establecidos por la teoría aristotélica de la educación; 3) existe un paralelismo entre palabra y música, ambos conceptos clave de la teoría fragmentaria de la educación esbozada en Política y Retórica. Con ello se concluye que la Retórica complementa la teoría educativa propuesta en la Política por Aristóteles.
\end{abstract}

Palabras clave: Retórica; educación en la antigüedad; jóvenes; discurso epidíctico; ethos; mimesis.

\section{Abstract \\ Rhetoric and education: an interpretative proposal of Aristotle's On Rhetoric}

During the fourth and fifth centuries BC, in the city-state of Athens, a lively debate developed around the question: how to educate? The mechanisms inherited from education, Homeric poetry and gnomic wisdom, began to be replaced by systematic theories of education. However, one of its greatest theorists, Aristotle, bequeathed us an incomplete theory due to the disappearance of the Politics books that contained his theory of education. In this article it is proposed that part of this theory can be reconstructed by making an interpretation of Rhetoric that focuses on the greek problem of education. It will be argued in favor of the following hypothesis: On Rhetoric contains sketches of a theory of education. Three arguments will be developed: 1) On Rhetoric contains a theory of education, because the young ones, one of the characters analyzed by Aristotle, are not a political entity. This implies that Aristotle does not think rhetoric only as embedded in politics, but also as having an educational scope. 2)The epidictical discourse theorized in On Rhetoric has an educational character, since its purpose is to transform the behavior of the young according to the canons established by the Aristotelian theory of education. 3) Show that there is a parallelism between word and music, both key concepts of the fragmentary theory of education outlined in Politics and On Rhetoric. Thus, it is concluded that the On Rhetoric complements the educational theory proposed in Politics by Aristotle.

Key words: Rhetoric; education in the antiquity; the young; epidicitic discourse; ethos; mimesis. 


\section{INTRODUCCIÓN}

Ciertamente vivimos en una comunidad política que contiene en sí formas de ser heterogéneas. El mundo griego ya se había enfrentado a esta conformación política y produjo un conjunto de reglas del discurso (retórica, dialéctica, filosofía, poesía, etc.) como la demostración con entimemas para movilizar afectos y talantes, es decir, caracteres. Todo esto para convencer al más acérrimo rival, producir homogeneidad, absorber lo diferente y alcanzar la estabilidad del cuerpo político.

Signo de ello es lo que Gorgias (1996, p.205 [Encomio a Helena §8]) apunta: “La palabra es un poderoso soberano que, con un cuerpo pequeñísimo y completamente invisible, lleva a cabo obras sumamente divinas". La palabra, además de tener un carácter político, tiene un carácter afectivo y ético. No sólo la demostración científica transforma al otro. El registro de la cultura, la instrucción y la educación también se moviliza con lo afectivo, político y ético.

La ciudad de Atenas al asumir un sistema democrático se enfrenta al problema de cómo reconstruir el antiguo orden aristocrático, donde los mejores se encargaban de los asuntos políticos, pues el sistema de gobierno democrático permite el acceso de las mayorías a la vida política.

Anteriormente, los aristócratas dominaban la escena política, luego, en la democracia, todo ciudadano podía permitirse participar en la vida política. Para hacer efectiva esa participación, los ciudadanos reconocieron que entre mejor se habla y persuade, mayor es la influencia política en la ciudad.

La única forma de resolver esa inadecuación entre el aristócrata y el plebeyo era la educación, es decir, la elaboración de una segunda naturaleza que potencia las habilidades para hablar y persuadir, y que no dependa de la estirpe. La excelencia, entonces, se alcanzaba por medio de la educación.

Con esa preocupación nace la sofística, pues su pretensión y su promesa era generar esa segunda naturaleza, ya fuera en la excelencia (virtud) o en el arte retórico, ambas técnicas destinadas a potenciar las dotes políticas del individuo. Este desarrollo implicó un estudio sistemático del lenguaje, la gramática, la literatura y la poesía para sustituir la fuerza de la estirpe por la fuerza de la palabra.

Por lo anterior, el lenguaje se vuelve un objeto más y se considera un instrumento. De ahí surge la pregunta por el uso óptimo y eficaz de dicho instrumento para persuadir al otro, para atraerlo y lograr una comunidad política.

Eso supone un proceso dialéctico: existe un individuo que quiere persuadir, que quiere imponer su punto de vista sobre el otro, mientras el que es objeto de la persuasión se opone y también desea imponerse. El resultado: el que logra utilizar el habla para persuadir de mejor manera, se impone.

Lo anterior implica la transformación del otro, una rectificación de lo que cree el otro, pues, luego de ser persuadido considera verdadero lo que antes consideraba falso. En fin, el otro es educado, instruido, cultivado a través de su transformación. Con esto queremos mostrar que la retórica implica educación, pues la transformación del punto de vista del otro se logra a través de la persuasión, dado que los enunciados han de ser persuasivos para que cumplan con su objetivo de modificar al otro y otras.

La educación requiere de persuasión y, por otro lado, toda persuasión implica una forma de educación, pues esta quiere imponérsele al otro y transformarlo.

Por lo dicho antes, se puede conjeturar que Aristóteles en su Retórica al describirla como "...la facultad de teorizar lo que es adecuado en cada caso para convencer" (Aristóteles, 1994, p. 179 [Ret. 1355b]), también desarrolla tácitamente parte de su teoría de la educación, en tanto que se establecen las bases teóricas: la forma lógica, los afectos y el talante que son adecuados para persuadir. 
Entonces, cabe preguntarse: ¿qué relación hay entre la educación y la teorización de la retórica hecha por Aristóteles? ¿Se puede extraer una teoría de la educación de la retórica aristotélica? Y ¿si lo anterior es cierto, en qué consiste dicha teoría?

\section{DESARROLLO}

\section{Proposición}

La hipótesis de trabajo es la siguiente: la retórica aristotélica contiene implícitamente una teoría de la educación que se puede reconstruir a partir del concepto de imitación y carácter, pues en tanto arte de la persuasión, teoriza en torno a los efectos pedagógicos de diferentes formas del discurso que influyen en el carácter a partir de la imitación.

En la presente investigación se sigue un plan que pretende desarrollar los siguientes argumentos: 1) la Retórica contiene una teoría educativa, pues el joven' ${ }^{1}$, uno de los caracteres reseñados por Aristóteles, no es una entidad política. Esto implica que el filósofo piensa la retórica no sólo como política, sino también como un tipo de arte con implicaciones educativas; 2) el discurso epidíctico tiene un carácter formativo, pues su finalidad es argumentar en torno a la virtud y el vicio; y 3) existe un paralelismo entre la palabra y la música, pues ambos son medios de formación del carácter a partir de la imitación.

\section{Argumentos para la discusión}

La retórica antigua no fue un campo monolítico y establecido, sino un campo de disputa donde confluían diferentes concepciones sobre las características y fines de la retórica. La retórica para Gorgias, Aristóteles, Platón e Isócrates estaba ligada a diferentes concepciones de educación, pues, en el mundo griego, el arte, la oratoria y la retórica transmitían un carácter, un sentimiento de intención por parte del artista (Bergen, 1994p.34).

Cada uno de esos autores tuvo una postura particular sobre el papel de la retórica en la ciudad:

1. Platón consideraba que todo arte retórico debía estar acompañado de responsabilidad política.

2. Gorgias de Leontinos, al contrario, proponía que la retórica era independiente de la responsabilidad política.

3. Isócrates postuló que la enseñanza de la retórica era una herramienta de producción de lo político (Haskins, 2006).

4. Los sofistas tenían una concepción muy variopinta de la retórica, por ejemplo, Protágoras, según Diógenes Laércio (Libro IX, 52), destaca el valor del momento oportuno en el discurso e introdujo

1. Optamos por la traducción "joven" y no hacemos uso del lenguaje inclusivo u otros usos más recientes como "persona joven" debido a que Aristóteles utilizó la palabra "véoc" que quiere decir "joven". Las traducciones más relevantes de Retórica, como la que usamos para este ensayo, utilizan la traducción joven sin utilizar lenguaje inclusivo. Se opta por ser fiel al texto aristotélico en griego por dos razones, primero, Aristóteles rechaza, por desgracia, que la mujer pueda ser parte de la vida política de la ciudad y, segundo, las traducciones no utilizan el lenguaje inclusivo. Por ello, la modificación hacia el lenguaje inclusivo podría tergiversar el sentido del texto o hacer más difícil o confuso la comparación de traducciones y la búsqueda de los pasajes relevantes para este ensayo. 
los trucos para las discusiones erísticas, cosa que nos lleva a pensar que Protágoras no considera necesario unir la responsabilidad política y la retórica.

Dicho esto, sobre el contexto en el cual se desarrolla la retórica y su relación general con la educación, se destaca que Aristóteles estableció una relación ambigua entre ambos términos, pues tal como apunta Haskins (2006) la retórica, para Aristóteles, no tenía la pretensión de producir conocimiento sobre política y cultura en los ciudadanos, sino que tenía un carácter impositivo al establecer los roles de los hablantes y las audiencias. Además, la definición de retórica como capacidad tenía como fin separar del contexto cultural la actividad retórica, instrumentalizándola, de forma que fuera útil a la hora de confrontar un auditorio con características que difieren del orador. Es decir, la retórica es una herramienta homogeneizadora de las creencias, el carácter y los afectos.

Ahora bien, la misma autora plantea que la imitación tiene un importante rol en la retórica aristotélica, en tanto que está tematizada a través del ejemplo.

Este elemento, la imitación, correspondería a un tipo de pedagogía que puede ser utilizada en niños de corta edad, de forma que estos construyan el hábito, ya que, según Aristóteles, todavía no poseen medios racionales para aprender.

Como se puede observar, la relación entre retórica y educación es ambivalente para Haskins (2006), sin embargo, la autora no presenta argumentos a favor de sus aseveraciones. Es necesario explicitar la conformación ética del joven, su carácter, su psicología y afectos para dar cuenta de la compleja relación entre la educación y la retórica aristotélica.

Oksenberg (1992) también discute la problemática relación entre educación y retórica. Termina su artículo con las siguientes preguntas: ¿Debería el retórico mejorar el carácter de la audiencia para llevarlos a la prudencia? ¿Debe el retórico educar a su audiencia, así como los persuade? Estas dos preguntas surgen del recorrido que hace la autora a través de la Retórica aristotélica, pues considera que el retórico presenta su argumento de manera que sea comprensible y conmueva a los caracteres presentes en la audiencia.

Además, al presuponer el conocimiento de la lógica y la ética, la retórica puede mostrar que el objeto de la deliberación es un genuino bien y el objeto de toda creencia una genuina verdad.

Esa clarificación parece mostrar algo nuevo e inédito para la audiencia, algo que ellos mismos que no sabían de sí. Así, el retórico parece educar sobre algo. Por ello, Oksenberg (1992) plantea que el prudente y el estadista necesitan de la retórica para lograr actuaciones públicas efectivas.

Oksenberg (1992) agrega que el discurso epidíctico descrito por Aristóteles tiene una función educativa al alabar o reprochar acciones, esto motiva e indica la virtud, además de estar dirigida al futuro, dándole así un carácter normativo.

Por otro lado, la amplificación y el uso de los ejemplos también se muestran como elementos retóricos pedagógicos. Sin embargo, Oksenberg (1992) sostiene que:

...the rhetorician attempts to persuade them of a particular decision or action, without being particularly concerned to educate or structure their fundamental interests [y agrega que]...not even the best rhetorician is concerned to bring his audience to a sophisticated philosophic understanding of their ends, or to promote general eudaimonia, all things considered (p.69).

Sin embargo, la misma autora apunta que el estadista necesita habilidades retóricas y tiene la responsabilidad de educar a los ciudadanos. Por ello, se puede considerar que Oksenberg (1992) se equivoca, pues su fluctuación respecto al carácter educativo de la Retórica se debe a que no reconoce las sutiles 
conexiones que hay entre retórica y educación que están dispersas por toda la obra aristotélica, ya sea la imitación o la conformación del carácter.

La discusión anterior indica que no hay claridad sobre el carácter pedagógico de la retórica aristotélica, aunque esta obra se encuentra inmersa en la discusión más general sobre cuál es la mejor educación para la ciudad-estado.

Sin embargo, lo expuesto por Oksenberg (1992) y Haskins (2006) anuncia que la retórica adquiere su carácter pedagógico a través de la acción política, pues, el estadista requiere de la retórica para educar a los ciudadanos, como condición para crear discursos afectivos dirigidos al auditorio. Esto implica que la retórica posee, por lo menos, algunos elementos pedagógicos como la imitación.

En consonancia con este carácter pedagógico de la retórica dentro del ámbito político, Lee (2001) sostiene que la educación ha de ser controlada por el Estado, cosa que hace de la educación una función eminentemente política.

Así, la educación se convierte en concepto de amplio espectro que no sólo contempla el conocimiento, sino que tiene un carácter ético, social y político, que logra su objetivo (crear hombres ${ }^{2}$ excelentes) a través de la educación moral, el entrenamiento de los hábitos y la habituación práctica (Lee, 2001).

Esto último remite de nuevo a la noción de imitación, pues la producción de una sociedad unitaria y unificada respecto a ciertos comportamientos ejemplares, se asocia a la producción de ejemplos, amplificaciones y discursos epidícticos que muestren lo que se debe imitar. De nuevo, la educación, en su rol político, adquiere herramientas de la retórica a la hora de producir la uniformización de la conducta.

Lee (2001), como los anteriores, no da cuenta del particular carácter educativo de la Retórica, pues solamente ingresa en el ámbito de producción de lo político y deja de lado las teorías de la educación expuestas por el Estagirita y de la especificidad del carácter del oven.

La retórica, por tanto, es una forma de controlar la conducta utilizando elementos de la ética, la lógica, la psicología, etc. Así, el hombre de estado o estadista logra articular estas formas del saber para persuadir a la audiencia, a partir de recursos retóricos como la imitación.

Apoyando lo anterior, según Haskins (2004) Aristóteles considera que los discursos están definidos en función de los efectos que tienen sobre las personas, ya sea el epidíctico o el forense, entre otros.

Lo apuntado por Haskins (2004) remite a lo indicado por Chambliss (1987), a saber, que toda teoría de la conducta, es decir, como se producen ciertas conductas, es una teoría de la educación, pues toda conducta es algo aprendido, así, la teoría sobre el tipo de conducta que se produce través de, por ejemplo, el mecanismo mimético de la retórica, es una teoría de la educación.

Al respecto vale la pena subrayar que la teoría retórica de Aristóteles comprende el vasto conocimiento de la época que se tenía sobre el ser humano, como la ética, la lógica, la psicología, la literatura. Es decir, todo el edificio aristotélico se concentra en la Retórica para dar luz a una teoría que explicaba cómo se comportaría la audiencia si escucha X o Y enunciado.

2. Aquí no es posible utilizar seres humanos, porque este término no existe en la lengua griega. Tristemente,

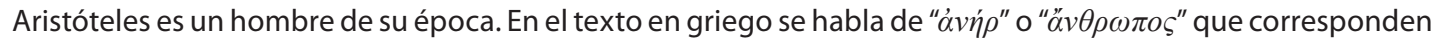
a "hombre". Recordemos que los únicos depositarios de un tipo de excelencia para Aristóteles son los hombres, mientras las mujeres quedan excluidas de toda participación política. La utilización de "seres humanos" causaría confusión a la hora de carear este ensayo con el texto griego u otras traducciones, pues no existe tal palabra en el vocabulario aristotélico. 
Así, la retórica aristotélica pretendió clarificar lo opaco para convencer, ya fuera a través del entimema lógico o del ejemplo pedagógico, que disuade sobre qué conducta observar en situaciones específicas.

Si bien solamente Oksenberg (1992) Ilega a plantear el problema al cual este ensayo se enfrenta, cierto es también que esa autora Haskins (2006) observan en el carácter mimético de la retórica una suerte de herramienta pedagógica que indica la existencia de una teoría de la educación en el texto denominado Retórica.

Por ello, el retórico tiene a su disposición un conjunto de herramientas pedagógicas que alcanzan su verdadero potencial en la ejecución de la política. Entonces, es claro que la imitación, ya sea en el ejemplo o en el discurso epidíctico, es la clave para revelar que Retórica teoriza implícitamente sobre la educación. La imitación es el camino para reconstruir la relación que existe entre la educación y la retórica, relación tan problemática y difícil de escudriñar.

Finalmente, cabe apuntar que estos autores olvidan dar cuenta del carácter explícito del individuo que se desea educar, por ello fallan a la hora de dar una explicación cabal de la relación entre educación y retórica.

\section{Reflexiones en torno al tema}

\section{La retórica como teoría educativa}

La producción teórica que elabora Aristóteles en Retórica requiere un esfuerzo de grandes proporciones, que nace de un problema de iguales proporciones. El problema no es nuevo: Platón polemiza con la retórica y la poesía, dos disciplinas estrechamente relacionadas con la producción de una segunda naturaleza o educación, pues es sabido que la retórica se desarrolla como una segunda naturaleza para desplegarse en un ámbito político que valora más la excelencia de la formación que la excelencia de la estirpe.

Así, la poesía es reemplazada como fuente de normas de conducta para la estructuración de la vida política. Todo esto quiere decir que Platón y lo que él considera filosofía pugnan por tener el papel principal en la vida de la ciudad, al tener la filosofía una pretensión educativa, en contra de la poesía y la retórica.

Aristóteles no escapa a esta problemática. Así, desarrolla en el libro VII y VIII de Política un pequeño extracto de su teoría de la educación. Con esto queremos decir, que Aristóteles, asumiendo el problema de su maestro, afirma:

Actualmente, en efecto, se discute sobre estos temas, pues no todos aceptan que haya que enseñar lo mismo a los jóvenes, ni en cuanto a la virtud, ni en cuanto a la vida mejor, ni está claro si conviene atender más a la inteligencia que al carácter del alma (Aristóteles, 1988, p. 456 [Pol. 1337a, 36-39]).

De la cita se puede extraer que es claro el carácter de disputa sobre los principios de la educación y lo que deben aprender los jóvenes. Esto quiere decir que Aristóteles asume el problema de su maestro, pero ¿por qué? ¿qué hace que Aristóteles teorice sobre el fenómeno de la educación?

Respondiendo a lo anterior, Hauser (1999) refiere que desde Solón el criterio de distinción entre los pobladores de la ciudad es la riqueza y no la estirpe, esto produce una tensión entre ricos y pobres, crímenes constantes y formas rudimentarias de castigo.

Así, surge la necesidad de formas de coerción débil. Esto se puede lograr en la esfera de lo público a través del discurso. Sin embargo, Hauser (1990) expone que, en dicho momento histórico, los oradores no eran 
muy confiables, pues eran oportunistas que defendían cualquier causa. Por ello, es de urgencia para el Estagirita dar cuenta de formas de coerción que permitieran controlar y educar a través del discurso público, pues Atenas, siendo una ciudad democrática, tuvo como lugar de producción política el lenguaje.

Por lo anterior, la retórica aristotélica estaba escrita para lidiar con la incertidumbre y las necesidades de una sociedad donde los ciudadanos eran libres. Se podría decir que es una respuesta al contexto en el que se encontraba el Estagirita. Todo esto conduce a preguntar, qué induce a pensar que, efectivamente, cuando Aristóteles escribe su Retórica, estaba pensando en el problema educativo que se planteaban los atenienses, entre ellos Platón y él mismo.

Para Aristóteles, es evidente que el teorizar sobre la educación es teorizar sobre el objeto ${ }^{3}$ sobre el que se ejecuta la acción de educar, pues es necesario saber cómo funciona el objeto que es educado. Así, teorizar sobre la educación es hacerlo alrededor de quienes son educados, a saber, infantes y las personas jóvenes.

Respecto de los infantes, Aristóteles (2001, p. 124 [EN 1119b5-7]) apunta que: “...viven de acuerdo con sus deseos y especialmente en ellos se da la tendencia de lo placentero". El niño, pues, está fijado en una forma anterior al razonamiento, pues sólo sigue el placer. Luego su capacidad para delibrar es nula, pues, si “...niños y animales persiguen los placeres" (Aristóteles, 2001, p. 226 [EN 1152b]), entonces, "...la tendencia a lo placentero es insaciable y está en todo para quien carece de sentido. La actividad del deseo incrementa lo que es congénito y si esas actividades son grandes e intensas incluso llegan a expulsar a la razón..." (Aristóteles, 2001, p. 124 [EN 1119b 8-10]).

De esto se colige que es necesario instaurar una disciplina para que la naturaleza innata no desborde al individuo. Aristóteles reconoce el peligro de un placer desbocado y por eso ha de ser controlado, pero sobre esto volveremos más adelante. Sólo resta decir que, si el niño no posee razón y no puede deliberar, entonces, es imposible que sea sujeto político, pues lo político está delimitado por el carácter deliberativo del ser humano, con el cual lleva a cabo acciones razonadas.

Ahora bien, todo esto implica que un infante no está en capacidad de deliberar, pues no está en mayoría de edad para hacerse cargo de sí. Incluso, según el criterio de Aristóteles, el infante es demasiado inmaduro incluso para ser educado (Aristóteles, 1988, p. 450 [Pol. 1336a]). Por lo tanto, la retórica no puede ser utilizada en ese estadio de la vida, sino después en donde se comienzan a presentar las condiciones de la educación.

Esto porque el infante, según Aristóteles, es sensación pura: sus placeres son inmediatos y no han sido impresos en la imaginación, ya que cada infante participa de los placeres irracionales y naturales, como los del cuerpo: la sed, el alimento, el sueño y los juegos (Ret. 1370a 10-25). Sin embargo, en el joven, que ya es susceptible de educación, aparece la imaginación, que se define así:

...como el tener un placer consiste en sentir una cierta afección y la imaginación es una sensación débil, [resulta que] a todo recordar y esperar acompaña siempre una imagen de lo que se recuerda y espera. Ahora bien, si esto es así, es claro entonces que los que recuerdan y esperan tienen simultáneamente con ello un placer, puesto que también tienen una sensación (Aritóteles, 1994, p. 266-267 [Ret. 1370a 29-32]).

3. Esto no quiere decir que las personas que son educadas sean objetos. Elegimos utilizar "objetos" por varias razones; primero, el texto aristotélico no contiene la palabra "sujeto", pues es posterior a la Grecia antigua y su inserción produciría desconcierto entre los lectores al no encontrarlo en las mejores traducciones en español ni en el texto griego; segundo, que aquí hacemos referencia a un principio metodológico aristotélico que no hace distinción entre sus objetos de estudio sean estos animales, personas o cuerpos celestes. 
En el joven aparece ya una espera y una memoria del placer, es decir, es posible afectar su imaginación, y aquí es donde inicia a perfilarse el carácter educativo de la Retórica, en tanto que el Libro ll de esta, que describe las pasiones, hace énfasis en que estas solamente se producen a través de la imaginación. Sin embargo, se debe delinear más el carácter del joven.

Los jóvenes sí pueden ser educados, pues Aristóteles en Política refiere que si algún joven es: “...sorprendido diciendo o haciendo alguna cosa prohibida... que se le castigue con vejaciones propias de hombres no libres..." (Aristóteles, 1988, p. 451 [Pol. 1336b 9-11]). Pasiones como la vejación, según el filósofotienen efecto sobre el joven, pues este tiene memorias y esperanzas, es decir, imaginación respecto de situaciones anteriores, donde sintió dolor o placer.

Como prueba de lo anterior, Aristóteles indica que el desprecio está unido a la ira, y esta se define como: "... un apetito penoso de venganza por causa de un desprecio manifestado contra uno mismo o contra los que nos son próximos, sin que hubiera razón para tal desprecio" (Aristóteles, 1994, p. 312 [Ret. 1378a30-32]). El joven según el Estagirita, espera o rememora cosas, por ello, su imaginación es susceptible de ataque por medio de la retórica. Y si bien no es un individuo político, sí es un individuo sujeto a la persuasión por parte de la retórica, pues esta le da herramientas al maestro para manipularlo a través de la estimulación de la imaginación, ya sea con lo doloroso o lo placentero.

Para observar cómo la retórica actuaría sobre una persona joven, debe observarse cómo se entiende el carácter del joven.

Para Aristóteles el carácter: “... debe ser una cualidad de la parte irracional del alma, pero capaz de seguir a la razón, de acuerdo con un imperativo racional" (Aristóteles, 1985, p. 69 [EU 1220b 5-7]). Esta definición es clave, pues hay una conexión entre lo irracional y lo racional del alma, cosa que permite el control de la razón sobre la irracionalidad. Esto quiere decir que el carácter está conectado con lo irracional, es decir, con el placer y el dolor que producen las imágenes, como en la definición de la ira.

En cuanto al carácter de joven, Aristóteles da dos descripciones. La primera es: "...los jóvenes son propensos a los deseos pasionales y de la condición de hacer cuanto desea. De entre los deseos que se refieren al cuerpo son, sobre todo, dóciles a los placeres del amor e incapaces de dominarse ante ellos..." (Aristóteles, 1994, p. 377 [Ret. 1389a 3-6]). Luego, Aristóteles apunta que:

La mayoría de las veces viven llenos de esperanza, ya que la esperanza atañe al futuro, mientras que el recuerdo al pasado: ahora bien, los jóvenes tienen mucho futuro y poco pasado; y no es, desde luego, propio del primer día recordar nada, sino esperarlo todo (Aristóteles, 1994, p. 379 [Ret. 1389a 20-25]).

También, agrega que los jóvenes son "...vergonzosos (porque no piensan aún en otra clase de acciones bellas, sino que sólo están educados según las convenciones)" (Aristóteles, 1994, p. 379 [Ret. 1389a2829]). y amplía diciendo que "...viven, en efecto, más según el talante que según el cálculo racional..." (Aristóteles, 1994, p. 380 [Ret. 1389a 34-35]). Finalmente, agregaaque el joven "...no es un alumno apropiado de Política... Más todavía, como el joven se deja llevar por las pasiones, escucha en vano y sin provecho..." (Aristóteles, 2001, p. 49-50 [EN 1095a 3-6]).

Con esto se tiene suficiente material textual para apoyar la tesis de que Aristóteles escribe la Retórica, en parte, por una preocupación educativa.

Este argumento es sostenible por las siguientes razones:

1. La Retórica necesariamente posee una preocupación educativa, pues para producir una ciudad virtuosa cada uno de sus ciudadanos ha de ser virtuoso (Aristóteles, 1988, p. 423 [Pol. 1329a]). Por ello, es necesario que se establezca una institución educativa encargada de dicha tarea (Aristóteles, 
1988, p. 435 [Pol. 1332b]). Ahora bien, teniendo esto en cuenta y pensando que la retórica está supeditada a la Política como ciencia superior, , porque “... el bien supremo es el fin de la Política y ésta pone el máximo empeño en hacer a los ciudadanos de una cierta cualidad e inclinados a practicar el bien" (Aristóteles, 2001, p. 65 [EN 1099b]), entonces, la Retórica como producción teórica está supeditada al bien supremo que es fin de la Política.

2. Se observa que el joven, según Aristóteles, no sería capaz de ejercer la vida política, a causa de su poca experiencia y exceso de esperanza, es decir, no ocuparía ningún papel en el campo del discurso forense o judicial, ya que no tiene ni voz ni voto en la esfera pública.Entonces, cabe preguntarse, ¿de qué sirve la teorización sobre un objeto que no está relacionado con el discurso para regular la vida política, fin de la Retórica, si la vida política es uno de sus principales fines?

A esta interrogante se puede contestar que, puesto que la retórica está supeditada a la política, tendrá un carácter educativo: por ello es que en esa obra se da cuenta del carácter del joven. También, cabe resaltar que la teoría sobre las pasiones esbozada en Retórica se puede considerar, siguiendo esa hipótesis, como una teorización sobre cómo manejar el carácter del joven, pues, el joven es más propenso a las pasiones.

3. Así, de acuerdo con Aristóteles, el hombre maduro que participa de la vida política, "...está claro que tendrá un talante intermedio entre los dos [anteriores], prescindiendo del exceso propio de uno y de otro: sin demasiada confianza... ni demasiado miedo, sino estando bellamente dispuestos para ambas situaciones..." (Aristóteles, 1994, p. 385 [Ret. 1390a 28-31]).

4. Además, para Aristóteles, joven es incapaz, psicológicamente, para ejercer la vida política, mientras que el hombre maduro está en todas sus capacidades para ejercerla, pues tiene la justa experiencia. Sin embargo, de nuevo cabe preguntarse ¿por qué Aristóteles teoriza sobre aquel que ni siquiera tiene la capacidad psicológica para ejercer la vida política? A esto se puede responder, de nuevo, que la retórica tiene un carácter formador a partir de la dominación del carácter, intermediario entre la vida irracional y la racional, pues al exponerse al joven a pasiones como el miedo, la compasión, la ira, entre otras, a través del discurso, se produce habituación, es decir, transforma al joven intemperante en hombre maduro capaz de virtud o excelencia.

Dicho todo esto, entonces, cabe preguntar por el tipo de discurso que produce en el joven, de acuerdo con Aristóteles, la habituación al dolor y al placer propios de la educación tal como la concebía este filósofo.

\section{El discurso epidíctico como formador de la juventud}

Ya se observó cómo se relacionan las pasiones y el carácter de las personas jóvenes jóvenes en Retórica. Ahora bien, en este apartado se establece el tipo de discurso que posee esta función educativa dentro de la esfera de los discursos públicos al afectar al carácter a partir de las pasiones.

Cada tipo de discurso posee su especificidad, de ahí que el discurso epidíctico se considere el más adecuado, pues este se encarga del elogio y la censura. Aristóteles antes de explicar los contenidos, métodos y objetivo del discurso epidíctico apunta que: "... hablemos de la virtud y el vicio y de lo bello y lo vergonzoso, pues éstos son los objetivos [que persigue] el que elogia y el que censura" (Aristóteles, 1994, p. 240 [Ret. 1366a 23-24]). Para Aristóteles (1994, p. 379 [Ret. 1389a28-29]) el joven, no puede reconocer lo bello por sí mismo, sino que depende de una ley externa que le presente lo excelente, lo malo, lo vergonzoso y lo bello.

Esto último implica que se necesita mecanismos externos para producir en el joven el reconocimiento de las leyes comunes por otros medios, es decir, a través del discurso epidíctico. Si se sigue la hipótesis planteada, la teorización sobre el discurso epidíctico no solo produce un efecto sobre el orador, sino que presenta a la audiencia de jóvenes, conforme a la ley común, lo que debe ser elogiado o reprochado, de 
forma que este se habitúe al placer o al dolor que se sigue de las acciones. Se podría pensar, también, que el discurso epidíctico genera un tipo de experiencia e imaginación en el joven que lo impulsa a seguir e imitar ciertas imágenes.

Ahora bien, es menester establecer qué debe seguir el joven, pues es claro que no se elogian las acciones en sí mismas, sino la intención. Obsérvese lo que dice Aristóteles (Aristóteles, 1994, p. 249 [Ret. 1367b 20-24]) sobre esto:

Ahora bien, como el elogio se hace las acciones y es propio del hombre virtuoso[actuar] de acuerdo con una intención, hay que esforzarse también, por otra parte, en mostrar que [el sujeto del elogio] ha actuado según una intención determinada, para lo cual es útil poner de manifiesto que ha actuado así ya muchas veces...

Este habituarse a observar la intención produce en el joven una memoria de la intención loable: las buenas son las elogiadas; las malas, reprochadas. Cabe apuntar que los infantes, en cambio, pueden escuchar mitos, pero el relato siempre se mantiene en la descripción de hechos, nunca alcanzan la descripción psicológica de la elección. Esto muestra que a la persona joven se le muestran modelos que le permiten construir cualidades éticas a partir del reconocimiento de la intención con que se lleva a cabo alguna acción, de aquí que Aristóteles elabore una teoría sobre los actos involuntarios, voluntarios y no voluntarios en la Ética Nicomáquea y Ética Eudemia.

No sólo hay una producción de imágenes sobre la intencionalidad, sino que también "El elogio es un discurso que pone ante los ojos la grandeza de una virtud" (Aristóteles, 1994, p. 249 [Ret. 1367b 27-28]). Esto se relaciona con la sensación, pues ante los ojos se presenta una imagen que produce placer y que va constituyendo poco a poco una memoria que lo invita a esperar lo que ha visto.

El elogio, además de ser un ámbito de producción de modelos para la memoria de la persona joven, también produce, a través del discurso, preceptos. Es bien sabido que, en el mundo griego, específicamente en los cantos fundacionales de poetas como Hesíodo y Homero, existen pequeños preceptos, normas gnómicas que pretenden regular la vida del común.

Ahora bien, el elogio cumple el mismo propósito, pues, “Por lo demás, el elogio y la deliberación son de una especie común, porque, si a lo que se preceptúa cuando se dan consejos se le cambia la expresión, eso mismo resulta en un encomio" (Aristóteles, 1994, p. 250 [Ret. 1367b 39-40]). Esto quiere decir que del elogio pueden nacer preceptos, pues si el discurso posee poder ético, entonces, también poseerá poder educativo debido a su normatividad.

Pero ese carácter normativo no es azaroso, sino que está vinculado con la ley común bajo la cual se forman los jóvenes. Aristóteles lo plantea de la siguiente manera:

En general, además, entre las especies comunes a todos los discursos la amplificación es la más apropiada a los epidícticos (ya que éstos toman en consideración acciones sobre las que hay acuerdo unánime, de suerte que sólo falta rodearlas de grandeza y belleza) (Aristóteles, 1994, p. 253 [Ret. 1368a 27-30]).

En esta afirmación hay dos suposiciones: (1) que el discurso epidíctico trabaja a partir de las leyes establecidas y en lo que todos están de acuerdo, de forma que este tipo de discurso tiende a reproducir en el joven un carácter común; y (2) que este está dirigido a producir sensación alrededor de un hecho moral, pues se rodea de grandeza y belleza, sensación que es más potente en el carácter de infantes y en jóvenes. 
Todo este discurrir sobre el carácter educativo de la retórica no es casual, pues, "Así pues, es evidente que la retórica no pertenece a ningún género definido... es útil y que su tarea no consiste en persuadir, sino en reconocer los medios de convicción más pertinentes para cada caso" (Aristóteles, 1994, p. 172 [Ret. 1355b 8-12]). Por lo tanto, la Retórica puede ser utilizada, y esto es lo que se sostiene en este ensayo, para dotar de herramientas discursivas al pedagogo, ya que, como es claro en la filosofía aristotélica, hay una urgencia por resolver problemas inmediatos de la sociabilidad como la corrupción moral de los oradores, el uso mal habido de la retórica, los problemas educativos, regular el ámbito del discurso público, entre otros.

Con lo dicho anteriormente, se desea cerrar la argumentación ofrecida explorando la música en tanto práctica esencialmente ligada a la educación, vista desde los actos discursivos teorizados como educativos por la retórica y la técnica en las perspectivas de Platón y Aristóteles.

De esta forma se logrará evidenciar con más fuerza el carácter educativo de la Retórica, pues si es verdadero que la música es el método por excelencia de la educación y la retórica participa de la música, se sigue que esta última participará de la educación.

\section{Música, palabra e imitación}

La música y el discurso no están separados en el mundo griego, pues resulta claro que ambos participan del sonido. Obsérvese cómo se define el adjetivo mousikós: "de las Musas; musical; músico; formado en el arte o en las ciencias, culto, fino. Substantivado. Arte de las musas esp. Música, canto; danza, baile; poesía; en gral. formación espiritual, educación superior, cultura; ciencia" (Pavón, 1967, p. 402).

Ese adjetivo se deriva el sustantivo moũsa que significa "musa, arte de las musas, ciencia, arte y esp. Poesía, música, canto" (Pavón, 1967, p. 402). Nótese el amplio campo que cubren las dos palabras: va desde el baile hasta las ciencias, pasando por un elemento crucial: la poesía, es decir, se trata de la tradición griega que cifraba toda educación en los poetas.

Ahora bien, si la poesía es educativa, entonces, produce efectos sobre la psique del oyente. Y como se indicó antes, esta posee sentencias gnómicas, lo cual refuerza su carácter educativo.

Siguiendo esta línea de pensamiento, Woerther (2008) observa que el elogio y la culpa se usan para habituar las almas jóvenes para que deseen lo que deberían desear y huyan de lo que deberían huir. Para controlar estos dos movimientos, se debe producir un tipo irracional de virtud, pues según la perspectiva aristotélica, los jóvenes no tienen ni opinión ni conocimiento reflexivo.

Obviamente este sería un gran escollo para cualquier teoría de la educación, pues, en el joven no se tendrían las características mínimas que permiten el convencimiento a través de los medios lógicos de la retórica, sino un carácter que es afectado por imágenes que se deben imitar.

Debido a esa particularidad de los jóvenes, también se debe desarrollar una teoría particular de la producción de los apetitos entre jóvenes. De esto se coligue la relevancia de la música como medio para la regulación del apetito, cosa que los pitagóricos apuntaban al sostener la existencia de una conexión misteriosa entre el mundo de los sonidos y el mundo del alma humana (Woerther, 2008).

Ese mecanismo educativo funciona así: los sonidos que produce la persona y las modulaciones vocales respecto a cierta actividad práctica son el objeto de una imitación musical, que consiste en armonía, ritmo y habla (Woterhter, 2008). Según esto, la relación entre habla y educación se afianza más, en consonancia con el carácter de la imitación que se produce en el discurso epidíctico.

La música afecta el mismo lugar de la psique que es afectada por los discursos, el carácter: "...pues, según el consenso de todos, éstas producen entusiasmo en las almas, y el entusiasmo es una afección del carácter del alma" (Aristóteles, 1988, p. 467 [Pol. 1340a]). El entusiasmo es un efecto que se produce en 
el alma por imitación, a partir de la capacidad del alma humana que se despierta con la música, habituando a las personas jóvenes a "...gozar, amar y odiar de modo correcto" (Aristóteles, 1988, p. 467 [Pol. 1340a18]). Y esto no es extraño, pues,

Parecen haber dado origen a la poética fundamentalmente dos causas, y ambas naturales. El imitar, en efecto, es connatural al hombre desde la niñez, y se diferencia de los demás animales en que es muy inclinado a la imitación y por la imitación adquiere sus primeros conocimientos, y también el que todos disfruten con las obras de imitación (Aristóteles, 1974, p. 135-136 [Poet. 1448b 3-6]).

Con esto se tienen las bases fisiológicas del proceso imitativo que se lleva a cabo en la música y en el discurso, pues es evidente que la imitación es constitutiva de la naturaleza humana, por lo tanto, el ser humano en su primer aprendizaje debe utilizar esta facultad para replicar lo dicho en el discurso o lo que se refleja en la música.

Ese argumento completa la hipótesis formulada en este ensayo, en tanto que la capacidad de imitar es una cualidad psicológica e innata en el ser humano, que puede moldearse a través del discurso epidíctico, el cual ofrece los ejemplos a ser imitados.

\section{SIINTESIS Y REFLEXIONES FINALES}

Se concluye que Retórica puede ser interpretado como un texto que complementa la teoría aristotélica de la educación, pues Aristóteles teoriza en ese texto sobre el carácter del joven, quien en su criterio no es parte del cuerpo político por su corta edad, pero sí es parte del conjunto de individuos que deben ser educados.

El joven es un hombre maduro en potencia y debe ser persuadido de lo que es bueno o malo a través de la manipulación de las pasiones que afectan su carácter, a partir de las imágenes ofrecidas a la imaginación que deben ser imitadas. Esta manipulación se produce a través del discurso epidíctico que tiene como fin el elogio y la censura, dos piezas claves para que el joven comience a observar y a producir memorias de lo reprochable y lo loable.

Por otro lado, la música, que Aristóteles considera de suma importancia para la educación, no está disociada del discurso, pues ambos tienen los mismos efectos sobre el carácter, al ser objetos de imitación por el alma de oyente. De esta manera, tanto el discurso epidíctico como la música producen imágenes que deben ser ofrecidas por los pedagogos para generar un tipo específico de carácter.

Así, se concluye que la preocupación de Aristóteles en la Retórica no es puramente teórica, es decir, además de ser un texto descriptivo, también, ofrece criterios para teorizar sobre la educación de los individuos que son parte de una sociedad democrática.

\section{REFERENCIAS}

Aristóteles. (1903). Ethica Nicomachea. Teubneri: Lipsiae.

Aristóteles. (1935). The Athenian Constitution. The Eudemian Ethics. On Virtues and Vices. Cambridge: Harvard University Press.

Aristóteles. (1959). Politics. Cambridge: Harvard University Press.

Aristóteles. (1960). Rhétorique (livre I). Paris: Les Belles Lettres. 
Aristóteles. (1960). Rhétorique (livre II). Paris: Les Belles Lettres.

Aristóteles. (1974). Poética. Madrid: Gredos.

Aristóteles. (1978). Acerca del alma. Madrid: Gredos.

Aristóteles. (1985). Ética Eudemia. México: Alhambra.

Aristóteles. (1988). Política. Madrid: Gredos.

Aristóteles. (1994). Retórica. Madrid: Gredos.

Aristóteles. (2001). Ética a Nicómaco. Madrid: Alianza Editorial.

Aristóteles. (2009). Rhetoric Vol. 1. New York: Cambridge University Press.

Aristóteles. (2009). Rhetoric Vol. 2. New York: Cambridge University Press.

Bergen, T. (1994). The Geeks and the Education of Humanity. The Journal of General Education. 43(1), 32-43.

Chambliss, J. (1987). A Necessary Truism: Educational Theories Are Theories of Conduct. Journal of Thought. 22(3), 6-1.

Hauser, G. (1999). Aristotle on Epideictic: The Formation of Public Morality. Rhetoric Society Quaterly. 29(1), 5-23.

Haskins, E. (2006). Choosing between Isocrates and Aristotle: Disciplinary Assumptions and Pedagogical Implications. Rhetoric Society Quarterly. 36(2), 191-201.

Haskins, E. (2004). Endoxa, Epistemological Optimism, and Aristotle's Rhetorical Project. Philosophy \& Rhetoric. 37(1), 1-20.

Grimaldi, W. (1980). Aristotle, Rhetoric I. A commentary. New York: Fordham University Press.

Grimaldi, W. (1988). Aristotle, Rhetoric II. A commentary. New York: Fordham University Press.

Laercio, D. (2007). Vida y opiniones de los filósofos ilustres. Madrid: Alianza Editorial.

Lee, J. (2001). Educational Thoughts of Aristotle and Confucius. The Journal of Educational Thought (JET) / Revue de la Pensée Éducative. 35(2), 161-180.

Oksenberg, A. (1992). The Directions of Aristotle's "Rhetoric". The Review of Metaphysics. 46(1), 63-95.

Pavón, J. (1967). Diccionario Manual griego-español. Barcelona: Vox.

Rorty, A. (2011). Aristotle on the Virtues of Rhetoric. The Review of Metaphysics. 64(4), 715-733.

Sofistas. (1996). Testimonios y fragmentos. Madrid: Gredos.

Woerther, F. (2008). Music and the Education of the Soul in Plato and Aristotle: Homeopathy and the Formation of Character. The Classical Quaterly. 58(1), 89-103. 